\title{
From False Consciousness to Class Consciousness: A Marxist Reading of Rawi Hage's Cockroach (2010)
}

\author{
Abdelhakim Fetnaci, Dr. Yousef Awad
}

Department of English Language and Literature, University of Jordan, Jordan Email: hakimfet@outlook.fr

\begin{abstract}
This paper aims at examining Rawi Hage's Cockroach (2010) from a pragmatic perspective, and specifically from a Marxist point of view, to see the ideological purpose that the novelist tries to unearth regarding the issue of life in a modern capitalist society. The novel imitates the external world only as a means to the ultimate end of intellectuality to guarantee a moral objective. Therefore, for the accomplishment of this task, the essence of this essay is to analyse Cockroach with reference to Marxist concepts such as; hegemony, capitalism, alienation, and revolution. As a matter of fact, it tends to trace the unnamed narrator's plunge from a false consciousness into a class consciousness realm.
\end{abstract}

Keywords-Cockroach, Class consciousness, False consciousness, Marxism, Rawi Hage.

\section{INTRODUCTION}

The Marxists inherit the belief that for literature to have a pragmatic orientation, it must not operate in a vacuum; "it is pre-eminently a social act as well as a social product" (Glicksberg, 1972, p. 1). It reacts and acts upon the social, economic, and political institutions that can be regarded repressive at the individual as well as the collective levels. It has to envelope a social content within its formative tissue; in the light of this, one may argue that it needs to be characterised as a 'literature of commitment' which aims at achieving positive political ends. It undertakes a 'social criticism' or a 'social protest' not hostile to the conception of society, however "to those aspects of society that are unjust, decadent, oppressive, (and) inimical to life" (p. 4). The writer, as a social critic, feels himself vindicated in his moral objection counter to a biosphere that is dehumanised and hegemonic. He takes a non-conformist stand as socially committed for a humanistic cause rather than falling in the trap of bourgeois literature. Hence, "in behalf of exploited mankind" he dwells in and "launches an impassioned literary crusade that will hasten the advent of the social millennium" (p. 6). It is this produced social effect that enables this kind of literature to function by virtue to unearth the dubious atmosphere of the macro together with the micro existence (p. 7). As a matter of fact, the Marxist approach appreciates the reconstructed bridge, which has been shattered by the
Formalists and Structuralists, between the literary work and the world of which it is a part.

\section{DISCUSSION}

The reciprocal relationship between literature and society is diametrically vibrant in Rawi Hage's novel, Cockroach, whereby his writing is firmly bound up with the cultural as well as the historical context. The unnamed narrator faces the dilemma that "everything was about defying the oppressive power in the world that (he) can neither participate in nor control" (Hage, 2010, p. 5); this epitomises all the miseries which any nomad character is exposed to in his journey of migration to the north. Montreal is a city that has been invaded by capitalists Parisians who thereabouts occupy the market of food in 'every Boulangerie' and 'croissanterie' (p. 27). Maitre Pierre, the head of the French restaurant in which the narrator has served for a period of time, turns to be a harsh dominant once he is approached for a job promotion by his servants; in a severe tongue without a speck of compassion he underestimates, to borrow Edward Said's term, the 'Other' with his colour as "the sun has burned (his) face a bit too much" (p. 30). Indeed, these stereotypical racist images are positioned as a result of the cultural determinism that forces the privilege of the quasi-superiority of the West over the inferiority of the East which breeds the issue of classes in a certain social order. Immigrants go to northern 
and western countries for refuge and build a flowering future, yet the dystopian reality crushes their souls forgetting that "it is these countries that make (them) leave (their) homes in the first place" (p. 223). The lie of welcoming the immigrants is not merely hindered by the cultural difference from which the characters come, but also by the classes they belong to.

It is the cultural determinism that plays a pivotal role in shaping marginalisation and legitimising, what Antonio Gramsci calls, hegemony, a term that stands for one of the major turning-points in the Marxist cultural theory. In other words, in his book, Marxism and Literature (1977), Raymond Williams argues that "the traditional definition of 'hegemony' is political rule or domination, especially in relations between states. Marxism extended the definition of rule or domination to relations between social classes, and especially to definitions of a ruling class" (p. 108).The lifestyle of the upper and the lower class is diametrically antagonistic whereby the "Bourgeois filth" owns all the materials for an opulent life; they live luxuriously with their fur coats and blue BMW cars, they also enjoy being in "fancy stores and restaurants... driving their forks into their mouths" while the baggers stare at them from the outside behind the thick glass (Hage, 2010, p.86-7). Therefore, as a case in point, because of this social hierarchy the two experiences of the narrator and his therapist, Genevieve, cannot converge; on the one hand, the former's existence is viewed through the lenses of a civil war he has left in his home country, Lebanon, and a journey of survival in Montreal, while for the latter it is all the opposite.

By the same token, as authority blinds whoever seizes it in his hand, the owner of the Indian restaurant is also a hegemonic character. Regardless of his prejudice against the working servants and the clothing of the narrator that does not fit with the fancy surroundings, he stands behind the bar watching everything as a master of the area with his, what Michel Foucault calls, surveillance of all the happenings. Through his attitude of giving orders with a menacing voice, he pulls the narrator towards the vacuum cleaner and fills his hands with a water bucket assigning him to clean the windows on the outside despite the bitter cold and blowing snow (p. 154). This determination "is always also a constitutive process with very powerful pressures which are both expressed in political, economic, and cultural formations and, to take the full weight of 'constitutive', are internalized and become 'individual wills"' (Williams, 1977, p. 87). Thus, the owner scarcely talks to him; sometimes one gets the sentiment that he does not even acknowledge his existence and when he does so, he "only uses his neck to point out" (Hage, 2010, p.264). He hates to see any of his employees standing doing nothing, therefore he turns to the narrator and sends him down for cleaning and once in the basement "his talking shoes called (him) back up to help the waiter" pulling tables together (p. 174). His commands forces the individual to be submit and even to make sure that he sees him "plunging (his) feet down the stairs and (his) hands down the toilet" for the sake of inclusion or access to be acknowledged by "this God-fearing establishment of" the manager (p. 187).

To remind his servants of the performativity of his hegemony, the owner transforms into an "erect Napoleon" whenever he hears laughter or noise in the kitchen; this alarms him of any signs of subversion or rebellion thus he finds it a proper chance to puff and blow in their faces expecting them to bow their heads down (p. 265). More importantly, as a corrupt boss he does not depend on his servants as eunuch and slaves in his restaurant for his own materialistic ends for the setting is also pivotal in marketing his business. In other words, Hage's portrayal of the fancy Iranian restaurant is quite momentous with its eastern style whereby "all the ornament... transport(ed) you to the east. It surrounded you with dunes, lanterns, and hand-made carpets that marched the brown plates flying from the waiter hands onto woven tablecloths". It echoes images from the Arabian Nights with the gentle music, "the dim lightning, the glowing red from the lanterns, and the gold atmospheric ornaments" (p. 65-7). As a matter of fact, the owner exoticises the East and commodifies it for his own benefits for that this representation goes hand in hand with the Western thoughts regarding the whimsical and the exotic East.

He exemplifies a true capitalist who is seldom determined to preserve, what Williams (1977) calls, his 'productive force' (p. 91). He looks down on the narrator and his friends, Shohreh and Fahroud, whose looking cannot be compared to his orderliness; i.e. he has a nose for poverty for the reason that the rich hates the poor and an impoverished presence might threaten his commerce (Hage, 2010, p.85). In the light of this, in the restaurant, when Shohreh feels sick the owner rushes to the narrator, careless about her condition, claiming that "(his) food is all clean. If she said that she had food poisoning, it is not true. She ate the same food as everyone else" (p. 219). He, indeed, only cares about the reputation of his restaurant for that a rumour of a poisoned food might cause the degradation of his income in a privatised world of economy that is eventually 'subordinated to the capitalist element' (Williams, 1977, p. 92). Hence to keep his status from any financial crisis he orders Reza to 
"stop bringing people (he) know(s) to this place". His engulfment bymarketing his food fosters him to climb the ladder of privatisation which signifies the consistent realisation of 'the principle of individualism' (Meszores, 1970, p. 28). He is good at forcing his Napoleonic position together with burying "his head behind the bar and lick(ing) his thumb as he folded the bills" (Hage, 2010, p156), once he raises his buried head from between his shoulders like a turtle he hurries towards his car pushing a plastic bag under the seat and locks the door (p,127).

Shaheed, the short Middle Eastern man, is even more dangerous and corrupt than his counterpart. Shortly after he plunges his foot out of the limousine, he is met with the warm greetings and bows of the owner like a monarch in a royal court. Therefore, it is worth mentioning that he is also an egomaniacand a capitalist character because he "obviously has money. He has power. He probably has some kind of diplomatic immunity. $\mathrm{He}$ is connected here". $\mathrm{He}$ is animmoral rich man who works for the Iranian government and benefits from this prestige for his owns stygian desires to jail Shohreh and forbid her "to speak, to cry, or even to breathe" (p. 246-8). Interestingly, he is, with every step, escorted by a Canadian bodyguard for he carries a file that contains information about the host country marketing weapons to Iran using these same local people for the accomplishment of their operation. Hage writes that "Canada! Montreal! This happy, romantic city, has an ugly side, my friend. One of the largest military industrial complexes in North America is right here in this town". As a matter of fact, the narrator's predicament is the greedy nature of the human beings; he argues that "people should pay the price for their crimes. Sometimes they don't... they just don't" (p. 244). These compradors are the filth of the postcolonial epoch within and outside the colonies; in this manner, Hage echoes Malik Bennabi's argument in his book الصر اع الفكري في البلاد المستعمَرة، for he believes:

The Thirds World elite are the filth of the planet and I do not feel any affinity with their jingling jewelry wives. Their arrogance, their large TV screens. Filth! They consider themselves royalty when all they are is the residue of colonial power. They walk like they are aristocrats, owners from the land of spice and honey, yet they are nothing but the descendants of porters, colonial servants, gardeners, and sell-out soldiers for invading empire (p. 159-60).

This imagery of filth is strategically used to describe the traces of the colonial powers in their capitalist elite agents of their colonies; they are worse than their predecessors because these people are the atrocity walking above the earth.

Karl Marx's rejection of 'mediations', which are the private property, exchange, and division of labour, formulate his critique of alienation that can be defined as "a mistake, a defect which ought not to be". It stands for the exhibition of the severe devastating effect of the "inhuman power" of capitalism on the nature of the human beings at the physical, mental, and social level of which he is part of (Ollman, 1976, p. 131). The narrator finds himself trapped in a world saturated with fiendish human beings and what really makes it worst for him is that he is primitive and uneducated. $\mathrm{He}$ feels himself, as a cockroach, ruthlessly neglected by life outside and even at home whereby the human agency is exposed to degradation; he identifies himself with the cockroaches found in his kitchen in the sense that they are both in an arena of survival of the fittest. He is a private individual of present-day social constitution thus divorced from his universal being in which he is metamorphosed into an animal because of these determinations (Meszaros, 1970, p 29).

The animalistic imagery forces him to be alienated from the entity of being fully human for, as the creature tells him, though he believes he belongs to something better and higher, he is merely a "vulture, living on the periphery" (Hage, 2010, p.201). He is alienated from his objective being in a modern capitalist society and he presents himself half animal in that he can perceive the barking of the dog as insults directed to him as 'pest', intruder', and 'thief'; he is regularly reminded of being an animal and especially a cockroach as the insect addresses him saying "you are one of us. You are a cockroach. But the worst part of it is that you are also human", interestingly, unlike in human world, he senses belonging and hospitality in the underground in which he can find his fellow-insects (p. 203). Therefore, this magical realism delineates the dreadful conditions of the faculty of the human.

It is certainly true that the narrator tastes the bitterness of the dark spaces because they remind him of his deprivations with ambivalent feelings, yet he has no other clue but to be drawn there. These dirty places and sombre corners give him an ecstasy of existence for that only in the underground and at night he is able to impose his own sound 
on the world around him. In his inorganic body, he loses "consciousness of a 'species being' i.e. a being that has the consciousness of the species to which it belongs, or... a being whose essence does not coincide directly with its individuality" (Meszaros, 1970, p 36). The bright places are out of his league and frighten him the most; he is utterly obsessed with escaping the sun and whenever he is exposed to the atrocity of the light he rushes for the curtains on the windows to close them (Hage, 2010, p.200). His home is dark and smelly yet he can find in it refuge in which he hides. He embraces the underground to camouflage himself from the outside world that is full of 'vampires'; existing underneath it, where he is used to live in dirt and hunger, seems to him a dire need for one to clearly see the filth of people on earthand escape the bitterness of its cold.

It is worth mentioning that the farther north one goes the colder it gets. The narrator in the freezing city of Montreal suffers from the shivery cold and curses the circumstances that have forced him to undertake his miserable journey to this harsh terrain. It is, indeed, a season that has no mercy on the toes of the narrator and the likes of him; a horrible symphony of cold that tells "go back where you came from if you do not like it here" (p. 193). He can do nothing about it except to dress in his 'armour', call it a day, and go back to his dark underground for that even the object outside as the public phones "stand like vertical, transparent coffins for people to recite their lives in" (p. 36). Sometimes he is the only creature in a dystopic sphere where silence is out loud. In this realm, the animosity of nature horrifies the narrator physically and even psychologically whereby it makes him feel 'vulnerable'; this cold weather it firmly tied to one's alienation from himself. As he crawls towards the clinic for an appointment with Genevieve, he stands outside the window of a clothing store not solely with a yearning for those pieces but also to look at his reflection; interestingly, in a Jungian psychoanalysis, mirroring reverberateshis identity crisis. Notbeing able to think clearly, he experiences a split of consciousness; a twoness of existences which are both his. He belongs to two spaces but maybe "being human is being trapped (and) to be an insect is to be free" (p. 207). He is not sure of anything and this unleashes his nervous conditions wondering and asking himself "where am I? And what am I doing here? How did I end up trapped in a constantly shivering carcass, walking in a frozen city with wet cotton falling on mi all the time? And on top of this all, I am hungry, impoverished, and have no one". He is doomedin a foreign land whereby he fights against hunger.
The fridge thief, the narrator who is "the scum of the earth in this capitalist endeavour",lives in an apartment that is cold all the time but this does not stress him as much as the sound of his stomach cries from hunger does (p. 141). As a refugee from a civil war, his hardship is typified in the food shortages he suffers from; his kitchen has only rice and leftovers and sometimes he feels triumphant to find a "miracle indeed! A forgotten can of tuna" floating at the back of the cupboards (p. 36). Hence, he either has to steal as his neighbour Abou- Roro has taught him or to go strolling here and there hoping to meet someone generous enough to offer him a speck of food. His starving condition pushes him even to invite himself into his neighbours' homes and once he is met with their generosity he, exultantly, saves his hot food on the counter where "not even the roaches with their massive egalitarian appetites would approach it" (p. 142). Thus, his appalling misery brings him to recognise that "I and the likes of me, who will wait for the wind to shake the branches and drop us fruit" in this filthy cosmopolitan city (p. 21). He is controlled by 'an external necessity' of hunger which echoes Marx's argument that man is forced to alienation from his own 'anthropological nature' (Meszaros, 1970, p. 54).

This hybrid narrator is, undoubtedly, the master of the underground which is a vast world in its own and a sourceof resurrection or, what Carl Jung (2014) calls, a 'process of individuation' that stands for embracing 'our innermost and incomparable uniqueness'. It demonstrates a course of becoming one's own self; hence it could be defined as 'coming to selfhood' or 'self-realisation' (p. 173). It is where a man turns to be a definite unique being achieving his individual qualities that are fulfilled through a psychological development which allows him to attain the "peculiarity of his nature". Jung argues that the purpose of individuation lies in divesting "the self of the false wrappings of the persona on the one hand, and of the suggestive power of primordial images on the other" (p. 174). Therefore, it is highly essential for a man to be cognisant of the imperceptible system that nests in his unconscious in order to overcome it.

For the narrator, passing the underground is the only way to the outside world (Hage, 2010, p.24). He has had the advantage of being "at a low angle like that close to earth and invisible" to scrutinise the filth of people in the city and subsequently to deconstruct it from within (p. 125). Significantly, his job at the Iranian restaurant signifies the pivotal turning-point in his life; it helps him, with degrees, reintegrate into society or at least to land a career for himself after all he has been through. It represents the place where he can also find satisfaction as it provides him with, the very 
thing he has been deprived from, food. It blurs the line between the humans and the insects whereby they are equally fed. Besides, the narrator finds improvement in his financial status for that now he can revenge for the past hunger with a sense of pride; he can pay the rent and even buy some groceries, bread and cheese for himself. This is all attributable to the fact that the city affords him money and a chance of changing his life for the better as he thought that "all one has to do is substitute one sensation for another. Changes. Life is all about changes" (p. 279). Furthermore, because of the weather gets warmer than before, as in a few weeks these streets will be crowded with people and thriving flowers and green gardens, a euphoric sense of existence has embraced him. An excitement he now experiences that might also bring together the shuttered pieces of his identity specifically as he goes to the mirror and aims the gun at the large cockroach facing him yearning for killing the reflection (p. 288).Hence, he resolves to strip himself from his persona, the mask of inferiority he used to wear, and the primordial images that might be an analogy of the forced stereotypes and dogma of the upper class compradors.

The hegemony of the masters and the capitalists that is forced on the narrator and boxes him in alienation must be countered by a resistance or a revolution. This transformation of the entire immense superstructure, Williams (1977) declares, "begins from the altered relations of productive forces and relations of production... (It) is a process in which 'men become conscious of this conflict and fight it out'". This social change springs from the proletariats in order to shake the forced pressures and limits of the existing powerful hegemony (p. 76-111). Thus the narrator's transformation has taken place progressively. Shortly after he recognises that his existence is deranged by the bourgeois filth in a capitalist city, he acknowledges the fact that he is "good at slipping under anything" so that he can enter anyone's house (Hage, 2010, p. 104). He reverses the intrusion by means of breaking into the houses of Helene and Genevieve though she has never invited him into her personal life; he gets there with a triumph sitting in her luxurious chair, having a warm drink, and stealing whatever he is in need of like clothes and shoes. Furthermore, despite the fact that he has been passive all his life and especially silent when he should have done something about Tony's brutish deeds against his sister, he eventually realises that counter-violence is the only way to atone for his past subordination.

To say it differently, he manages to make his way into the industrialist's apartment, 'the manufacturer of filth', and turns towards his son's closet whereby the gun is kept with which he is going to turn everything upside down ( $\mathrm{p}$, 280). All in all, when Shohreh fails to revenge the abuses committed by her jailor, Shaheed, an epiphany, or a class consciousness, comes to the narrator's spirit and urges him to act immediately, therefore, to accomplish his full transformation into an active subject, he walks back to the counter and picks up a knife to stick it in the Canadian bodyguard's liver. Then without a moment of hesitation, which might take him all the way back to the circle of paralysis, he takes the gun and aims it at Shaheed with a double discharge (p, 305). As a matter of fact, "we have then to add to the concept of hegemony the concepts of counterhegemony and alternative hegemony, which are real and persistent elements of practice" (Williams, 1977, p. 113); simply put, overindulged with rage, he turns the restaurant, the place of dirty bargains, into a bloody arena of revenge. Interestingly, Frantz Fanon's The Wretched of The Earth (1963) meticulously exemplifies this reaction to the violence committed by the colonisers, or the compradors in this context. He argues that "decolonization is always a violent phenomenon"; therefore the narrator's freedom must take place through a 'counter-violence' for it "transforms spectators crushed with their inessentiality into privileged actors... it brings a natural rhythm into existence, introduced by new men" (Fanon, 1963, as cited in Karim \&Lawrence, 2007, p 79)

\section{CONCLUSION}

In a nutshell, Hage is committed to shed light on aspects of communal life and demonstrates the manners in which the group or the individual is formed and violently determined by the leading institutional groups that are found at the level of capitalism in which he is a constituent part. The character becomes conscious that he is at the mercy of hegemonic forces that marionette his existence on a collective basis. He realises that he has to submit to the passivity that is imposed on him till he turns to be trapped in the belief that his freedom is minimised to the extent where he can no longer sense that he is the agent of his own fate; he is merely "a functional part of a vast social machine and must obey its mandates" (Williams, 1977, p108). Yet, one must also acknowledge the deeds that are performed by, what Marx names, the proletariats once they start to have a 'consciousness' of the misery they are in. Throughout the process of criticising the atrocities together with the brutish spirit of greed and aggrandisement, Hage portrays a nonconformist character who, subsequent to the demoralising conflicts and calamities of life under hegemony, resolves to 
undertake a rebellion and a revolution counter to the quasisupremacy.

\section{REFERENCES}

[1] Glicksberg, C. I. (1972). Literature and Society. Dordrecht: Springer Science \& Business Media.

[2] Hage, Rawi. (2010). Cockroach. New York: Norton \& Company.

[3] Jung, G. Carl. (2014). Two Essays on Analytical Psychology. London and New York: Routledge.

[4] Karim, Aisha and Lawrence, B. Bruce. (2007). On Violence: A Reader. USA: Duke University Press.

[5] Mészaros, Istvan. (1970). Marx's Theory of Alienation. http://napoletano.net/cursos/geomarx 2018a/textos/Meszaros2005.pdf

[6] Ollman, Bertell. (1976). Alienation: Marx's Conception of Man in a Capitalist Society. Cambridge: Cambridge University Press.

[7] Said, Edward. (1979). Orientalism. New York: Vintage Books.

[8] Williams, Raymond (1977). Marxism and Literature. New York: Oxford University Press. 